expressed the view that the foundation in this country of an institute in which investigations on the causes and best means of preventing and curing infectious diseases can be carried on, and in which protective material can be prepared in sufficient quantity to supply the national wants had become necessary, and that it was neither fitting nor politic for England to be dependent on foreign laboratories.

The President and Council of the Royal Society considered the subject of the proposed institute, and expressed " their satisfaction that steps are being taken to establish an institution in which researches in bacteriology and into the nature and prevention of infective diseases can be carried on, and the hope that at some future time they may find it within their power to aid such researches by material support." The Council of the British Medical Association also expressed its approval of the idea of a national institute for the study of bacteriology, and agreed "to recommend a grant of $£ 300$ towards the expenditure of the current year."

I am not a member of the Lister Institute, nor am I in a position to express an opinion as to whether its record has justified its establishment, if its present organization and management are satisfactory, if these require remodelling, or are capable of being satisfactorily remodelled, but as I was intimately and actively associated with the initiation of the scheme which called it into existence, and took some part in the secretarial duties at a period when an appeal was being made for funds, I hope I may be allowed to express the conviction that any action which would diminish the facilities for independent and unfettered research would be a violation of the principles on which the institute was founded, and a perversion of the intentions of the initiators.-I am, etc.,

Jno. Penberthy Late Professor of Pathology
Royal Veterinary College.

Newnham, Gloucestershire, August'12th.

\section{"ENCYCLOPAEDIA MEDICA."}

Sir,-Since writing to you last in reference to the manner in which Messrs. Green and Sons advertise their Encyclopaedia Medica (June 13th, p. 331) a new prospectus, dated July 14th, has been issued by this firm. It professes to contain "A list of contributors to the first edition, with the addition of the names of those who have so far agreed to contribute to the second." It is hard to believe, but it is a fact, that my name is included amongst these, in spite of my previous letters to the medical press on the subject, and in spite of the fact that Messrs. Green had not yet asked for my permission or consent. I have written to them, and their answer begins: "We have your letter, and thought this matter had been adjusted previously, and cannot understand why you should have written to us as you do." The letter then goes on to ask whether I am prepared to revise or to refuse to revise my articles for the new edition, and the final sentence reads, "that every contributor, so far as we know" (italics are mine), " is going to revise." This statement does not appear to agree with the statement from the prospectus which I have already quoted.

It will be interesting to linow how many of the contributors in this prospectus have actually agreed to revise, or have only agreed in the mind of Messrs. Green.I am, etc.,

Dublin, August 17th.

HeNRy Jellett.

\section{Athùiral Aatuz.}

OWING to the necessary curtailment of the number of pages in the weekly issues of the BRITISH MEDICAI JOURNAL, all correspondents are particularly requested to write as succinctly as possible.

THE fourth edition of Sir Alfred Pearce Gould's Elements of Surgical Diagnosis, revised by the author, with the assistance of Mr. Eric Pearce Gould, is announced for early publication by Messrs. Cassell and Co.

WITH regard to the inquiry at the instance of the Brighton Insurance Committee on July 1st, as to an application from a drug store for restoration to the list of insurance chemists (as reported in the JOURNAL of July 4th, p. 28), we are informed that the Insurance Commis. sioners have decided to take no action.

\section{Ifetters, fintes, and Anturers.}

Queries, answers, and communications relating to subjects to which special departments of the BRITISH MEDICAL JOURNAL are devoted will be found under their respective headings.

\section{LETTERS, NOTES, ETC.}

A WARNING.

A Physician in London writes: On May 30th rou inserted a warning against a dusky complexioned man aged about 65, who was obtaining money from medical men. Two weeks ago he succeeded in obtaining a loan of money from me by representing himself to be a Canadian doctor, who was stranded in London owing to the war: an excuse wnich appeared reasonable but which I am now convinced was false.

WAR AND MOTHERHOOD.
(From a (Correspondent.)

OF course the vicar talked about the war, and presently he remarked with pride that a nephew of his, in the Flying Corps, had crossed to Belgium yesterday. "War," I said wisely, "has always been a murderous job, but if there's one corps in which a man can make sure of getting killed, its the Flying Corps." The vicar, looking graver than I expected, rejoined in a low tone, "He was to have been married next month." "Poor chap! Poor girl !" I groaned. "They wanted to get married before he started," continued the vicar dismally, but I said " No, leave the girl free." "Kinder for the girl in the long run," I assented. "But its a delicate problem; and there are thousands of such cases occurring all over Europe at the present moment." "Yes," cried the vicar warmly, "These hasty marriages ought not to be allowed. One night together, then the bride is left pregnant ; and soon "True," I said, "But isn't there another way of looking at it? The men who go to the front are the pick of the nation's manhood." "They are," said the vicar proudly. "And they'll get killed by the thousand," I continued. He nodder impatiently. "Then," I said, "once a war begins, the coming generation will have to be, in the nature of things, begotten by the sickly, the decrepit, and the maimed." "Its " ought not a far-seing nation to encourage its fighting mell to stamp their likeness on their wives before they go to get killed ?" "But, Good Heavens," he cried, " the danger to morality! the ultimate cost!" "War always has been a danger to morality," I said, "and it always has been costly. But the danger you refer to might be met by the State endowing the motherhood of only those wives whose children are born within ten months of their husbends loving hom to fight. And the cost, though heary, would aid murdering of useful human beings but theuld ald hot the human beings who may become useful," "I see," stalwart vicar with a watery smile: "You would consider it as a vicar with a watery smile: "You would consider it as a

$$
\text { The Cause of Cancer. }
$$

VICE CoTIS writes: Dr. Arthur Todd-White, in the Tocrsal of August 15th, alludes to the possibility that cancer may arise as a result of the excessive ingestion of food preservatives. This suggests a still wider possible source of cancer. We ali know that almost the only indisputable point in regard to the know that almost the only indisputable point in regard to the causation of cancer is that it can be produced by chronic tigation whether or not the deposition in the tissues, or cells thation whether or not the deposition in the tissues, or cells themselves, of insoluble sharp crystals of microscopic size produces a chronic irritation resulting in cancer? Such the people and parts of the body specially subject to cancer.

$$
\text { Corrections. }
$$

Is reference to Hoffmann and Kochmann's solution in the JOURNAL of August 8th (p. 302, col. 1, lines 10 and 11 from foot) the proportion of potassium sulphate was incorrectly given as 4 per cent.; it should have been 0.4 per cent.

DR. D. E. ANDERSON desires to correct two errors in the note of his remarks in the brief summary of the proceedings of the Section of Tropical Medicine published on August 10th, page 303. He said that vomiting sickness was known only in Jamaica, and that 16 cases had been reported in 1912. With regard to yaws, he said that both in Jamaica and Trinidad yaws had been reduced since the introduction of salvarsan.

\section{SCALE OF CHARGES FOR ADYERTISEMENTS IN THE} BRITISH MEDICAL JOURNAL.

Seven lines and under Each additional line
A whole column

A page

Än average line contains six $\ldots$

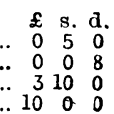

All remittances by Post Office Orders must be made payable to the British Medical Association at the General Post Office, London. safeguarded.

Advertisements should be delivered, addressed to the Manager. 429, Strand, London, not la ter than the first post on Wednesday mornin preceding publication, and, if not paid for at the time, should be NoTE- - It is against the

restante letters addressed rules of the Post Office to receive postes 